\title{
Editorial: Large-Scale and Full-Scale Laboratory Test Methods for Examining Wind Effects on Buildings
}

\author{
Gregory A. Kopp* \\ Boundary Layer Wind Tunnel Laboratory, Faculty of Engineering, University of Western Ontario, London, ON, Canada
}

Keywords: natural disaster mitigation, wind loads, large-scale testing, components and cladding, wind tunnels

\section{Editorial on the Research Topic}

Large-Scale and Full-Scale Laboratory Test Methods for Examining Wind Effects on Buildings

The idea for this Topic originated at a special session of the 3rd United Nations Conference on Disaster Risk Reduction entitled "Necessity and Efficiency of Large-Scale Facilities for WindRelated Disaster Risk Reduction," in Sendai, Japan in 2015. There has been significant growth in losses caused by disasters around the world (see Figure 14 in Tamura et al.), which this conference series is attempting to address. Losses caused by severe storms dominate the overall losses, with houses, the places where we live, where we shelter during storms, being disproportionately damaged or destroyed. In contrast, engineered buildings tend to perform better, although cladding systems remain vulnerable.

\section{OPEN ACCESS}

Edited by:

Forrest Masters,

University of Florida, United States

Reviewed by:

loannis Zisis,

Florida International University,

United States

${ }^{*}$ Correspondence:

Gregory A. Kopp

gak@blwtl.uwo.ca

Specialty section:

This article was submitted to Wind Engineering and Science,

a section of the journal

Frontiers in Built Environment

Received: 23 March 2018

Accepted: 16 April 2018

Published: 03 May 2018

Citation:

Kopp GA (2018) Editorial: Large-Scale and Full-Scale Laboratory Test

Methods for Examining Wind Effects

on Buildings.

Front. Built Environ. 4:25.

doi: 10.3389/fbuil.2018.00025
Engineered buildings tend not to have major structural failures, even in the most severe tornadoes. When structural failures do occur, they are (i) often preceded by a cladding/component failure such as a large window or door, which causes internal pressurization and subsequent overloading, or (ii) a fastener failure, caused by inappropriate consideration of the load path in design. This contrasts with earthquakes where the ground shaking tends to first cause failures of major structural components. So, in earthquakes, one tends to see collapsed buildings while in severe wind storms one sees an exposed structural system with the cladding missing. Once cladding fails during a storm, two things happen: (i) debris enters the wind field which can significantly increase damage downstream (Kaye, 2018), and (ii) rain and wind can enter the building, destroying the contents (Sparks et al., 1994). Wind-borne debris is also a significant life-safety issue, particularly in tornadoes, as discussed by Simmons and Sutter (2011).

As Prof. Yukio Tamura stated so eloquently and succinctly in his presentation in Sendai: "wind resistant design $=$ cladding/component design." To improve the design process for structures in severe storm conditions, many new, large-scale, and novel methods have been developed. Many of these are represented by this collection of papers. These include large-scale or full-scale wind tunnels (Moravej et al.; Haan; Standohar-Alfano et al.; Tamura et al.; Ge et al.), full-scale pressure testing systems (Miller et al.; Shen et al.), other full-scale methods (Boughton et al.), and computational approaches (Kareem and Kwon; Shen et al.).

Wind loads for use in design are typically obtained from scale model tests in boundary layer wind tunnels. Requirements in building codes are based on data from such facilities. However, wind tunnels were historically built to determine loads on high-rise buildings at model scales of 1/300 to 1/500. For low-rise residential structures (Tieleman, 2003), or for multi-layer, air-permeable cladding on high-rise buildings, such scales cannot resolve critical geometric details (Kopp and Banks, 2013). In many cases, it may only be possible to determine loads on full-scale structures. This implies a need for larger wind tunnels, four of which are described in this collection, that can test full-scale cladding and fastener systems placed on relatively small, but complete, buildings. 
In the controlled laboratory environment, wind loads can be measured along with actual responses or failures, providing a missing link in understanding performance that cannot be obtained from post-event field surveys alone. While there are no papers using full-scale field studies in this collection of papers, such methods are also of critical importance for validation of all test methods and improved fundamental understanding of the physical process including details about the wind field and the wind loads (Levitan and Mehta, 1992; Liu et al., 2009).

Cladding systems are manufactured products, so they are designed according to various product test standards. For wind resistance, many of these standards are based on simple, inexpensive load tests. The advantage of these test methods is their simplicity and low cost, while their disadvantage is that they often eliminate the correct physics such that passing a test does not guarantee good performance in practice (Kopp et al., 2012). One such example is (ASTM D5206, 2013), which eliminates the mechanism of pressure equalization for air-permeable, cladding system, and (ASTM Standard D3679, 2013), which interprets the loads incorrectly. This leads to loads that can be low by a factor of two (Moravej et al.; Miller et al.). Developing simplified and costeffective pressure-based test methods is one of the goals of these new labs so that the product test standards are, ultimately, a better indicator of real performance (Miller et al.; Shen et al.). Rain-water intrusion is a significant challenge and cause of losses. While water can be introduced in pressure-based systems, realistic simulations can be developed in full-scale (and large-scale) wind tunnels as demonstrated by Standohar-Alfano et al.

\section{REFERENCES}

ASTM D5206 (2013). Standard Test Method for Windload Resistance of Rigid Plastic Siding. West Conshohocken, PA: ASTM International.

ASTM Standard D3679 (2013). Standard Specification for Rigid Poly Vinyl Chloride (PVC) Siding. West Conshohocken, PA: ASTM International.

City of Moore (2014). Available online at: www.cityofmoore.com/sites/default/ files/main-site/high-winds-codes-passed.pdf

Haan, F. L., Balaramudu, V. K., and Sarkar, P. P. (2010). Tornadoinduced wind loads on a low-rise building. J. Struct. Eng., 136, 106-116. doi: 10.1061/(ASCE)ST.1943-541X.0000093

ICLR (2018). Durham Region Climate Resilience Standard for New Houses. Toronto, ON: Institute for Catastrophic Loss Reduction.

Kaye, N. B. (2018). Wind-Borne Debris Hazards. Reston, VA: American Society of Civil Engineers.

Kopp, G. A., and Banks, D. (2013). Use of the wind tunnel test method for obtaining design wind loads of roof-mounted solar arrays. J. Struct. Eng. 139, 284-287. doi: 10.1061/(ASCE)ST.1943-541X.0000654

Kopp, G. A., Morrison, M. J., and Henderson, D. J. (2012). Full-Scale Testing of Low-Rise, Residential Buildings with Realistic Wind Loads. J. Wind Eng. Ind. Aerodyn. 104-106, 25-39. doi: 10.1016/j.jweia.2012.01.004

Levitan, M. L., and Mehta, K. C. (1992). Texas Tech field experiments for wind loads part I: Building and pressure measuring system. J. Wind Eng. Ind. Aerodyn. 43:1565.

Liu, Z., Prevatt, D. O., Aponte-Bermudez, L. D., Gurley, K. R., Reinhold, T. A., and Akins, R. E. (2009). Field measurement and wind tunnel simulation of hurricane wind loads on a single-family dwelling. Eng. Struct. 31, 2265-2274. doi: 10.1016/j.engstruct.2009. 04.009
A topic of emerging importance is the design of buildings, communities, and critical infrastructure for tornadoes. In light of recently devastating events, several communities are requiring tornadoes be considered in design (e.g., City of Moore, 2014; ICLR, 2018). As a result, several new tornado simulators (Mishra et al., 2008; Haan et al., 2010; Sabaheesh et al., 2012; Refan and Hangan, 2016) have been built to provide wind loads and improved understanding of the wind fields associated with these events. The paper by Haan provides some significant new information about tornadic wind loads. Resilient communities and societies rely on the performance of civil infrastructure during severe events. The survival of transportation and power systems are critical. The paper by Ge et al. describes tests of a super-long bridge at the bounds of what is physically possible to build.

While improved test methods will improve our understanding of failure mechanisms and performance, design wind loads, and product test standards, designers and engineers need to be able to compute these things. The paper by Kareem and Kwon describes one such approach. It is hoped that by developing these new large-scale and full-scale research facilities, disseminating the subsequent research to various stakeholders, and engaging leaders in our communities, that losses caused by severe wind storms can be significantly reduced. There is a lot of work that remains to be done.

\section{AUTHOR CONTRIBUTIONS}

The author confirms being the sole contributor of this work and approved it for publication.

Mishra, A. R., James, D. L., and Letchford, C. W. (2008). Physical simulation of a single-celled tornado-like vortex, Part A: Flow field characterization. J. Wind Eng. Ind. Aerodyn. 96, 1243-1257. doi: 10.1016/j.jweia.2008.02.063

Refan, M., and Hangan, H. (2016). Characterization of tornado-like flow fields in a new model scale wind testing chamber. J. Wind Eng. Ind. Aerodyn. 151, 107-121. doi: 10.1016/j.jweia.2016.02.002

Sabaheesh, G. R., Matsui, M., and Tamura, Y. (2012). Dependence of surface pressures on a cubic building in tornado like flow on building location and ground roughness. J. Wind. Eng. Ind. Aerodyn. 103, 50-59. doi: 10.1016/j.jweia.2012.02.011

Simmons, K. M., and Sutter, D. (2011). Economic and Societal Impacts of Tornadoes. Boston, MA: American Meteorological Society.

Sparks, P. R., Schiff, S. D., and Reinhold, T. A. (1994). Wind damage to envelopes of houses and consequent insurance losses. J. Wind Eng. Ind. Aerodyn. 53, 145-155. doi: 10.1016/0167-6105(94)90023-x

Tieleman, H. W. (2003). Wind tunnel simulation of wind loading on low-rise structures: a review. J. Wind Eng. Ind. Aerodyn. 91:1627. doi: 10.1016/j.jweia.2003.09.021

Conflict of Interest Statement: The author declares that the research was conducted in the absence of any commercial or financial relationships that could be construed as a potential conflict of interest.

Copyright (c) 2018 Kopp. This is an open-access article distributed under the terms of the Creative Commons Attribution License (CC BY). The use, distribution or reproduction in other forums is permitted, provided the original author(s) and the copyright owner are credited and that the original publication in this journal is cited, in accordance with accepted academic practice. No use, distribution or reproduction is permitted which does not comply with these terms. 